\title{
MILITANT ORTHODOX FRINGE: POLITICAL PROGRAMS OF EARLY 21ST CENTURY SERBIAN RIGHT-WING ORGANIZATIONS
}

\author{
Srđan Mladenov JOVANOVIĆ, PhD \\ Nankai University, Tianjin \\ Email: smjovanovic@nankai.edu.cn
}

\begin{abstract}
Serbian contemporary fringe Right Wing groups have seen scant interest in scholarship. In this article, we tackle what we have dubbed the militant orthodox fringe Right Wing, namely by investigating their political programs. The groups confronted here are Obraz, 1389, SNP Naši, and the newest addition to the Serbian Right Wing political scene, the Serbian Right. Their political programs will be tackled via their own bullet points, then to be contrasted to existing theoretical scholarship on the Right Wing.

Keywords: Serbia, Right wing, Orthodoxy
\end{abstract}

\section{Introduction}

Serbia, together with its adjacent states, have seen copious scholarly production, especially after the Yugoslav wars of the nineties (Biserko, 2013; Djokić \& Ker-Lindsay, 2010; K. Hudson, 2003; Iveković, 2002; Jiménez \& Ángel, 2012; Kolstø, 2016; Lucarelli, 2000; 0'Shea, 2005; Pajnik \& Kuzmanić, 2005; Pavković, 2000; Perica, 2002; Sabrina P Ramet, 2005; Sell, 2003; Stojanović, 2015), Serbia itself figuring heavily as a topic of analysis (Aleksov, 2008; Bataković, 2012; Bieber, 2003; Damjanović, Novaković, \& Obradović, 2003; Ejdus \& Subotić, 2014; E. Gordy, 2004; E. D. Gordy, 1999; R. Hudson, 2003; Kaser \& Halpern, 1998; Morus, 2007; Nielsen, 2010; Sabrina P. Ramet \& Pavlakovic, 2007; Thomas, 1999; Žerjavić, 1998). Though many of the mentioned works touched heavily on Right Wing issues, not too many gave overviews of fringe Right Wing groups within the country, with the exception of a few articles (Babić, 2015; Dzombic, 2014).

In this article, we shall tackle the official political programs of four fringe extreme Right Wing groups in Serbia, with some emphasis on the new Serbian Right (Srpska Desnica), recently to start figuring heavily in the Serbian media and political life, arguably emerging from the fringe and into the center of attention (Beta, 2019; Congradin, 2019; Espreso, 2019; M., 2019; Tašković, 2018). Beside the Serbian Right, we shall tackle Obraz, 1389, as well as SNPNaši. Methodologically, we shall categorize their promoted Weltanschauungen, observing them through the lens of existing scholarship on the Right Wing, authoritarianism, and Serbia itself.

The Serbian Right Wing can be located in its European context, especially with the recent increase of Right Wing activity throughout Europe, however, with an important distinction. Right Wing activity in Serbia can be traced to the Yugoslav wars of the 1990s, whilst the recent 
increase in Right Wing activity in Europe is more connected to the recent refugee crisis (Decker, 2016; Rheindorf \& Wodak, 2018; Stier, Posch, Bleier, \& Strohmaier, 2017), which, even though it had not instigated it, enabled the West European Right Wing to flourish. The Serbian Right Wing, however, is closer related ontologically and geopolitically to Russia, which has officially followed such policies since the coming into power of Vladimir Putin. Russia's Orthodoxy, similarly, gives impetus to the Serbian Right Wing, and we shall see, in the text that follows, Serbia's Right Wing's strong connection and drawing on Russia figure heavily in their ideologies and policies.

\section{Obraz}

The organization known as "Obraz" (oft "Otačastveni pokret Obraz") is an extreme Right Wing association of Serbian Orthodox nationalists with hard-lining, extreme views. It grew from the initial Publishing house Serbian Obraz, founded in 1994 by Nebojša M. Krstić and Andrija Mladenović. It had never been overly active prior to 2000, and the founder, Krstić, died in a car accident in 2001, later to be opined on by his followers as "one of the first victims of Belgrade's Eurouniate regime, as he fought with all his strength against globalist evil and because he believed with all his soul that Serbia will be resurrected" (BSKM, 2013). It was then taken over by Mladen Obradović, who will later get prosecuted for violent behavior at the Belgrade Pride festival, convicted, and then have his conviction overturned by Court of Appeals (Tanjug, 2016b).

Their main tenets are "devotion and patriotism", a "Serbian Serbia", "homekeeping order", as well as "knightly armed forces". ${ }^{26}$ Orthodox Christian devotion and patriotism are seen as cornerstones and presuppositions of the existence of the Serbian people, as "without healthy Christian spirituality, there cannot be a healthy Serbian society". It is taken for granted that Serbia had seen its "golden age" and heyday in the $13^{\text {th }}$ century, under the rule of the Nemanjic dynasty, when, as Obraz incorrectly assumes that "all Serbs were of the Orthodox religion back then". The obsession with the Nemanjić dynasty is a common go-to motive within Serbian nationalism, as it is often seen as a utopia that has gone by, never to return. The "Serbian Serbia" tautology is based on the complaint that Serbs "are the only nation in $21^{\text {st }}$ century Europe that has not solved its national question", its "state-creating space is continuously being diminished and broken". This "Serbian national question" centers around the perceived "disappearing" of the Serbian nation, that is seen as being under attack from "Shqipetar terrorists, Islamic fundamentalists, Ustashas, and NATO occupying forces". Similar to the concepts of Lebensraum or spazio vitale, this idea of a "Serbian space" differs, essentially, in the lack of a colonial effort (Giaccaria \& Minca, 2016; Smith, 1980). The third pillar, "homekeeping order", is defined as "Cod is the host to the world, the Christ-loving ruler is host to the state, and the pious Serb is the host to the family". The medieval idea of a "knightlike military", the fourth pillar, claims that Serbia is located at a geopolitical and strategic crux, and that it is consequently "a target for many of the world's powerholders". Thus, it should have "fearless armed forces, imbued with the knightly

26 From: https://www.obraz.rs/osnovna-nacela/ including all subsequent quotes 
spirit of heroism and valor. The connection between authoritarianism and militarism is far from a novel one; Verhey has noticed that myths, in this case, the myth of the Nemanjic Golden Age, often go together (Verhey, 2000).

The Obraz stand for what they call a "national education".27 The coming generations should be educated "in the Saint Sava spirit of piety, nobility, and patriotism". The particular brand of Saint Sava Orthodox nationalism is a common, tired trope within Serbian nationalist circles (Đorđević, 2009), having seen many iterations since the wars of the nineties. Obraz' ideal indoctrinative practices are given in bullet points, starting from their idea of how language functions. Note that linguistic nationalism (linguonationalism) is also a common point of departure for "nationally minded" individuals and organizations (Kordić, 2010). There is a mystical, almost magical pseudolinguistic view of the language: it, "in a mysterious and and concentrated way contains within itself the whole soul, the whole past, the whole spiritual assembly, and the whole creative thoughts of the nation". The child should thus not be taught foreign languages before it has mastered its mother tongue entirely. Prayer is yet another among the key concepts of a national education. The prayer, conducted "in the Serbian language ... will bring the child spiritual harmony". Similarly, the child should be instructed in Serbian history, Serbian military, as well as "Territory".

The Obraz gained in notoriety when they published the "Announcement to Serbia's Enemies", in which they listed people, mostly of liberal political orientations, whom they threatened to "root out" and "punish" (Cvetković, 2009).

\section{9}

1389 self-describes as a "movement" that also an "Orthodox state-creating people's humanitarian society", one that deals in "conserving spiritual, historical, cultural, and other traditions of the Serbian people and affirming tradition". ${ }^{28}$ Its founding principles are those of Christian Orthodoxy, wherein they stress, rather similarly to Obraz, the dynasties such as the Nemanjić, Karađorđević, and Obrenović Serbian dynasties, including the Russian Romanov dynasty. Historical facts such as those about the Nemanjićs and Obrenovićs going against each other did not seem to create a cognitive dissonance within the proclamation. They were formed in 2004 by Borko Kostić, Marko Manojlović, Srđan Novak, and Radojko Ljubičić, and they claim that they have the blessing of the Patriarchate of the Serbian Orthodox Church to organize pilgrimages. They boast an English, Russian, and French version of their prime directives:

"Movement 1389 is non-government, non-profitable, anti-fascistic, social, youth organization registered in Belgrade, capital of Serbia, on February 21st 2005 (link). Our main aim and 1st chapter of Statute is: to preserve tradition and also affirmation of culture, historical, spiritual and other values of Serbian people. Name "1389" is after great battle between Serbian and Turkish army on Kosovo pole (central part of Kosovo and Metohia) in year 1389, when almost all Serbian and Turkish soldiers died as well as both tzars, and Europe was saved from Islam aggression.

27 From: https://www.obraz.rs/nacionalno-vaspitanje/ including all subsequent quotes

28 From: http://www.1389.org.rs/onama.html including all subsequent quotes 


\section{Security}

We respect and cherish Orthodox religion and Orthodox church. We are dedicated on defending sovereignty and territorial integrity of Serbia, which especially means keeping Serbian south province Kosovo and Metohia inside national borders. Kosovo is our sacred land, core of identity and cradle of Serbian history and we are working against independence of this province and in support of Serbs living in Kosovo. We are against Serbia entering European Union and NATO alliance, and for state alliance with Russia ... Our methods of work are peaceful and legal."29

Interestingly, the above seen English version emphasizes that the organization is "anti-fascist", same as the French one ("Le mouvement 1389 est une organisation de jeunesse, sociale, antifasciste, non gouvernementale et sans but lucratif enregistree le 21 fevrier 2005 a Belgrade, dans la capitale serbe"30), while the "about" section in Russian does not exist, nor does alleged "anti-fascism" figure in the only relating section about its organization:

“Движение '1389' было образовано в начале октября 2004 года в целях сбора прямых и существенных, но несколько хаотичной энергии из немногих родственников и друзей. Созрело понимание которое может быть сказанно словами 'если не сейчас, когда?' и 'кто, если не мы?' Сербский народ в большой биологической, моральной, экономической и любой другой кризис и мы должны принять судьбу в свои руки, чтобы вырвать от апатии. Абсолютно ясно что, к сожалению, нет отдельных лиц или учреждений, которые могут (и хотят) авторитетом и харизмом повести нацию, и поэтому все должны задаться вопросом, Что я могу сделать для страны? ... Название '1389' ссылатся на Косовскую битву, на поворотный момент в сербской истории и нашей фирмой решении служить Богу в справедливости, а не силой. ${ }^{\text {"31 }}$

The 1389 movement is clear in enumerating its pro et contra in a bullet point list, and their claims are that they stand for patriotism, Orthodoxy, unity, the conservation of the purity and richness of the Serbian language, the Cyrillic script, family values, state sovereignty and territorial integrity of Serbia. They also claim that they are against "sectarianism" and "unionism", drug abuse, the gay movement, as well as "(organized) crime and corruption". The stand against the "gay movement" is the only one that goes into additional detail, and tackling it reveals a strong homophobic sentiment behind it:

"The second half of 2009 brought about a surge of initiatives aimed at popularizing and promoting homosexuality and other sexual deviations, which until recently had been reported by the World Health Organization as a disorder. Even though we do not want to fall into the sphere of personal emotional and sexual choices of the citizens of Serbia, the field of public life should be protected from indecency, hideousness, anti-Christian and anti-traditional activities, that is, from gay parades, that are the authentic product of Western civilization, and in Slavic Orthodox countries, they represent an anti-civilizational phenomenon that seriously threatens basic social values, cultural patterns, spiritual norms and family values. We stand, on the basis of the following, for the view that same-sex orientation should remain in the sphere of privacy and that public promotion would cause

29 From: http://www.1389.org.rs/about-organisation-movement-1389.html including all subsequent quotes

30 From: http://www.1389.org.rs/mouvement-1389-en-francais.html including all subsequent quotes

31 From: http://www.1389.org.rs/organizacija-na-ruskom.html including all subsequent quotes 
unprecedented social harm and cause instability; the negative consequences would be particularly pronounced on children"32

Homophobia (often veiled under the alleged concern for public health, decency, or children) is almost a hallmark property of Right Wing movements in Eastern Europe, from Russia to Serbia (Czarnecki, 2007; Mestvirishvili, Zurabishvili, lakobidze, \& Mestvirishvili, 2017; Moss, 2014; Mršević, 2013), often connected to religion (Reygan \& Moane, 2014), and often seeing Serbia as the topic of scholarly interest (Mršević, 2013; Stakic, 2011).

\title{
SNP Naši
}

The SNP Naši, founded in 2006 by Ivan Ivanović (in 2010 to join with SNP 1389 - Miša Vacić into a single organization), formerly a member of Obraz. Their political program commences with the following paragraphs:

\begin{abstract}
"SNP NASI aims to make Serbia a society of opportunity, which is fair to all its citizens. We intend to fully support and encourage the independence and initiative of every citizen of Serbia in accordance with the Constitution and law. The success of every citizen in life should be a direct consequence of his talent, honest work, civic activism and adherence to the law, as opposed to illegal enrichment at the expense of others, and should be viewed in society as a mortal sin, and such people deserve every form of social contempt. and adequate punishment. We want a free, independent and prosperous state whose national and national interests provide a strong socio-economic, defense resource and intellectual potential. These national and state interests reflect the aspirations of the entire people and what the present and future generations of our citizens want".33
\end{abstract}

The quote above, with the exception of "mortal sin" and "adequate punishment", cannot be described as overly extreme. Yet the core tenets that they propound are "Serbian patriotism and domestic order", via which the abovementioned should be attained. The core concept is that of "Eurasian integrations", an increasingly common trope in Serbian Right Wing agendas. The very concept of Eurasia has had its day in scholarship from a wide variety of researchers, with an equally wide variety of interpretations and political agendas (Ismailov \& Papava, 2010; Kazharski, 2019; Lukyanov, 2014; Papava, 2013), and the term itself has seen numerous semantic shifts throughout the time, as it "moved from geology to culture and race, to describe children of ethnically mixed couples, and was in widespread use, for instance, in identifying those born from French-South Asian couples by the French administration in colonized Indochina" (Laruelle, 2016, p. 129). The contemporary concept of Eurasia, however, refers to what Trenin called a "Russia-plus" zone (Trenin, 2001, p. 110), one that is utilized to, to use IR rhetoric, establish Russia as a hegemon, with orbiting subordinate states, closely related to the concept of Russkiy mir (Pieper, 2018). Though Serbian Right Wing groups often stress the wish to distance Serbia from being a subordinate to the West, as they are "opposed to the pro-Western parties

32 From: http://www.1389.org.rs/ne-gej-pokretu.html including all subsequent quotes

33 From: https://nasisrbija.org/program-3/ including all subsequent quotes 


\section{Securitity}

in Serbia, whose commitment to the European Union and Euro-Atlantic integration lead to an ascending loss of statehood, economic devastation, moral and spiritual obstruction, destruction of all perspectives and all values of Serbian society", being Russia's subordinate is, somewhat paradoxically, seen as positive. This is in large part due to the perception of the West as being highly negative, as "Eurasian integration is Serbia's liberation from blackmail and anti-human politics, which is based on the whims of savage narcotics administrators of pro-Shipetarian, pro-fascist and pro-American orientation, and on whose principles, we are witnessing, rests with the European Union". This is in line with Russia's (somewhat extreme) anti-Westernism that has been part and parcel of the country for a while (Duncan, 1998; Umland, 2012). In a geopolitical binary, this Weltanschauung splits the world into the West and the East, or, better to say, the West vs the East. Russia has played an important role in Serbia during the last several decades, often seen as the "Mother Hen" to Serbia, a helpful hand in fending off what the Right Wing understands as the nefarious "West" (Biserko \& Stanojlović, 2016). Russia's Orthodoxy is oft seen as a utility in foreign relations (Coyle, 2018; Martin, 2019), and has been used by Russia to officially embrace Serbia under its wing. The Eurasian concept used by the SNP Naši is dubbed the "Panarin model" of Eurasian integrations, where, somewhat naively, Belgrade is seen as the "fourth capital" of Eurasia, after St. Petersburg, Kiyiv, and Almaty.

After Eurasia, the SNP Naši offer the second pillar of their policy, which is dubbed "social justice", one that includes the "fight against all that violates the institution of family and moral society, and by that we mean drug addiction, the so-called gay movements... etc". Homophobia rears its unseemly head yet again, where the distancing from the LGBT population is discursively achieved by naming it "so-called". The third bullet point can be understood in a broader political and historical context as stemming from the ideology of "Great Serbia": "the liberations and unification of all Serbian countries into one Serbian state". The maliferous ideology of Great Serbia (Melicharek, 2014; Popov, 2008; Zakošek, 2008) is an aging one, wherein Serbia is seen to need to exist as a larger state, which would potentially include most of former Yugoslavia, and has been used to justify the atrocities of the wars of the nineties. They define the term "all Serbian countries" as "the entire territory of today's Republic of Serbia with its provinces of Kosovo and Metohija, as well as Vojvodina, the Republic of Montenegro, the Republic of Macedonia, the Republika Srpska and the Federation of BiH, as well as the territory of the occupied RSK with territorial extensions and the northern part of the Republic of Albania".

Their "program principles" rest on primarily "patriotism" and the Orthodox faith, in yet another unattainable and guileless idea that "Serbia is bound to be one of the world's leading spiritual powers and a spiritual state in the new historical era. Our traditional spiritual and cultural values and our competitive advantages, combined with the key factor of contemporary economic growth - scientific and technological advancement, can and should provide a solution to the historic task of state-building prosperity of Serbia in the third millennium". Religious zealotry and an authoritarian view of the functioning of the state are seen in the notion that a "State Council for Spiritual and Moral Information Policy" and an "Advisor to the President of Serbia for spiritual and moral information policy" should be introduced at state-level. Beside 


\section{Security}

that, "family values" are also given a bullet point on their own: "Traditional values and family are the foundation for each individual's growth and upbringing. The family is the refuge and the first cell of the society in which each individual is formed, so our Orthodox tradition plays a large role in the formation of the child's personality, in order to protect him from the onslaught of anti-culture coming from particular Western countries, and which is embodied in sectarianism, drug addiction. materialism, individualism, ideologies of the gay movement, and other deviant groups". This paragraph embodies the entirety of a typical Right Wing ideology, from the ill-defined "family values", via religion, to homophobia, with an additional stance against individualism, which would figure heavily in an authoritarian ideology (Madureira, 2007); scholarship has located the increased emphasis on anti-individualism in former Yugoslavia in the war-engulfed nineties (Golubović, 1995).

\section{Srbska Akcija}

The "Serbian Action" is arguably the most militant Orthodox group tackled in this work. Their program and ideology immediately stress combat and Orthodoxy, saying that the "Serbian Action is a joint combat activity and the joint persecution of Orthodox Serbian patriots, which aims to awaken the Serbian people from the existing lethargy, moodiness and existence in the false peace of the stagnant spiritual bar of the New Age". ${ }^{34}$ According to them, they "want to persist in the fight for the survival of the Serbian people and the restoration of the Orthodox faith in today's Serbs. Our goal is to return to the cherished Serbian ideals and values that adorned our illustrious Ancestors". The perception presented is that Serbs, as a people, are about to perish, and that immediate action is necessary. This is to be attained through "a nationalist, authoritative and functional republic". Yet again do we seen the nation-state concept come into play, as "the state is a legal and political expression of a particular people and must therefore be regulated in accordance with its laws of life in order to guarantee its physical, spiritual and social protection". This state should be organized on the territory of the Great Serbia, as "in terms of territoriality, the Serbian state should be unique and include as much of the Serbian fatherland as possible, which is now largely occupied. With the exception of present-day Serbia (including, of course, Kosovo and Metohija), Serbia's fatherland belongs to: Montenegro, Krajina (with Slavonia and Dalmatia), Bosnia, Herzegovina and Southern Serbia (Macedonia)". Notably, none of the programs advocating for Great Serbia do explicitly use the term.

Interestingly, they too stress the concept of "social justice", which "cannot be attained with the system of the man being a slave to the state (Communism), or the system i which the man is slave to another man (Capitalism)". Instead, "establishing a Christian system of national solidarity" will have the desired, beneficial effects. Thus, the "strengthening of the social consciousness about social justice ... cannot be attained absent nationalism as the connecting tissue and the foundation of the defense of the state". A larger question here remains outside the scope of this work, and it is the question of "social justice". The concept was arguably put forth to the public

34 From: https://akcija.org/o-nama/ including all subsequent quotes 


\section{Securitity}

eye with the notorious Catholic Anti-Semitic priest, father Charles Coughlin (1891-1979), who in the late 1930s published his Anti-Semitic periodical, Social Justice (Boyea, 1995; Warren, 1996). Theodore Abel wrote on Hitler's Germany as having developed "a strong patriotic feeling which demanded the unity of the German people and a desire for social justice" (Abel, 2017) as well, noticing the importance of the concept to the Right Wing. The question remains how it had by the beginning of the $21^{\text {st }}$ century been appropriated by the Left in the West in a truly staggering amount of scholarly work of, for lack of other words, diverse quality (Adams \& Bell, 2016; Bastia, Piper, \& Prieto-Carron, 2011; Hahn Tapper, 2013; Rogers \& Kelly, 2011; Rosenthal, 2016). This, however, is a question for a different work, and perhaps even a different time.

\section{Srpska Desnica}

The newest addition to the Serbian Right Wing scene are the, by no means ignorable, "Srpska Desnica" (the Serbian Right), led by the former 1389 leader, Miša Vacić. The Serbian Right present four primary instances as the core of their political program: 1) traditionalism, 2) patriotism, 3) a healthy society and "unity", and 4) Eurasian integration. Said traditionalism is defined as an "insistence on tradition as the basic criterion for the organization of society" (All quotes from the program are from: Srpska desnica 2018); this traditionalism is pitted against the perceived "loss of national identity", and is comprised of "patriarchal society, Orthodox Christian faith, the respect for and maintaining of institutions that protect the very identity (the symbols of the hero, the father figure, mother, family, military, work, the host, the principle of authority, the principle of societal hierarchy, a monarchist principle)". The patriarchal society has solid roots in the Balkans (Kaser, 2008; Kaser \& Katschnig-Fasch, 2005), and Serbia itself - at least on its Right Wing fringes - still possesses patriarchal elements (though they are found primarily in rural areas; note the distinct divide between rural and urban Serbia).

The second theme, yet again, is "patriotism", which is perceived by them as "only constructive and beneficial relation towards one's own people", wherein it is revealed that said patriotism works in relation to the concept of the nation-state, as "the state is and should be an instrument of the Serbian people, so these two terms overlap a great deal". This Weltanschauung in effect relieves Serbia from either caring or enabling a modern lifestyle to all those who are not Serbs, and is by some regarded as xenophobic as well(Pajnik \& Kuzmanić, 2005). It is further expanded by a dumping of keywords from the nationalist repertoire: "family, traditions, behavior of the individual and the society, societal forms and structures, language, script, industry, symbols, political life, theory, information, and culture". Note as well the inclusion of language as a key point in the nationalist worldview, a trope that has been analyzed in scholarship, with the conclusions that language indeed serves as an important topic to the Right Wing (Kordić, 2010).

The third theme can loosely be translated as "unity" or "togetherness", one which "stems from Orthodoxy"; it is "the unison of all elements of the society and the acting towards the same direction through a combined effort", though it is not significantly elaborated upon. The fourth, however, is the already seen concept of "Eurasian integrations". It sees "spiritual, cultural, historical, linguistic, and national" ties with Russia, emphasizing that it "does not belong to the 
Atlantic corpus of states, but instead organically belongs to the space of Eurasia, the centre of which is occupied by Russia," in an iterating anti-Western view.

The Serbian Right can be seen as the more important among the tackled Right Wing groups within this work, as it has boasted its 6\% election result in the town of Medveđa (Latas, 2019; M., 2019), where Miša Vacić publicly boasted about driving in "14 jeeps" and leading people to vote for him (Čongradin, 2019). He further, and without punity, proclaimed that he would "drown" Nebojša Zelenović, an opposition politician, in the "Serbian river Drina" (N1, 2019). Vacić was further seen as working for the government prior to his engagement with the Serbian Right as an "advisor" for the Office for Kosovo and Metohija, the director of which, Marko Đurić, first publicly decried (Tanjug, 2016a), and then firing him from the position he allegedly did not occupy (Beta, 2017). It was consequently concluded that Vacic is an "extended hand of the government, he speaks what the government thinks, but dares not say ... the only thing he has are resources, that he is receiving in a questionable manner, as well as space in the media that was given to him by those whom he works for" (BBC, 2019).

\section{Conclusion}

In summa, the abovepresented groups have much in common, and stress either the same, or identical ideational tropes within their programs. The core tenets are based in Christian Orthodoxy, though emphasis needs to be made on the fact that the particular type of Orthodoxy is Serbian Christian Orthodoxy, commonly connected to St. Sava and the concept of "svetosavlje" (St. Savaism, for lack of existing translations). Said concept is crucial to the understanding of contemporary Serbian Right Wing, as the common nationalist discourses tend to draw on Orthodoxy with an allegedly specific Serbian note, which is found in the figure of St. Sava, who can be said to represent the main starting point of a specifically Serbian type of Christian Orthodoxy, especially having in mind that he was the founder of the Serbian Orthodox Church, having campaigned with success for its autocephaly in 1219.

The concept of Great Serbia (Velika Srbija), though never put into words directly, is yet another common instance, wherein the Right Wing group will consider that neighboring states should be incorporated within an enlarged, ethnically-based Serbia. Thirdly, expected concepts such as those of "patriotism" and "nationalism", essentially taken as synonyms, are common as well. The devotion to the nation is of prime importance, and it is strengthened by a strict adherence to Serbian Christian Orthodoxy. Yet another concept of high relevance is that of "Eurasian integrations", stemming from a perceived connection with Russia, and, in particular, to Vladimir Putin's regime. Connected also via perceptions of Orthodoxy, but also homophobia and nationalism, Russia figures as a cornerstone in potential foreign policy, in the forbidding, though unattainable, scenario of these groups attaining power.

The one group that would deserve to see further analysis is the new Serbian Right, with its leader, Miša Vacić. Having in mind that they are already acting with impunity within the state of Serbia, and having in mind that they have recently formed a coalition with the Socialist Party of 
Serbia (a member of the government coalition, ergo, officially in power), they arguably present the single burning question within the scholarly analyses of the Serbian Right.

\section{References:}

1. Abel, T. (2017). The Nazi Movement: Routledge.

2. Adams, M., \& Bell, L. A. (2016). Teaching for diversity and social justice: Routledge.

3. Aleksov, B. (2008). The new role of the Orthodox Church in Serbia. In M. Hélie-Lucas (Ed.), The Struggle for Secularism in Europe and North America (pp. 353-375).

4. Babić, M. (2015). Defining Political Extremism in the Balkans. The Case of Serbia. International Studies. Interdisciplinary Political and Cultural Journal, 17(1), 73-90.

5. Bastia, T., Piper, N., \& Prieto-Carron, M. (2011). Geographies of migration, geographies of justice?: feminism, intersectionality, and rights. Environment and Planning A, 43(7), 1492-1498.

6. Bataković, D. (2012). Serbia's Kosovo Drama. Čigoja. Belgrade.

7. BBC. (2019). Ko je Miša Vacić: "Srpski Julije Cezar" ili "politička starleta". 021. https:// www.021.rs/story/BBC/228014/Ko-je-Misa-Vacic-Srpski-Julije-Cezar-ili-politicka-starleta.html

8. Beta. (2017). Đurić: Smenjen Miša Vacić. Večernje novosti. http://185.29.102.55/vesti/ naslovna/politika/aktuelno.289.html:646289-Djuric-Smenjen-Misa-Vacic

9. Beta. (2019). A Career: Misa Vacic, Leader of the Serbian Right. Briefing. https://betabriefing.com/biographies/biographies/8976-a-career-misa-vacic-leader-of-the-serbian-right

10. Bieber, F. (2003). The Serbian opposition and civil society: Roots of the delayed transition in Serbia. International Journal of Politics, Culture, and Society, 17(1), 73-90.

11. Biserko, S. (2013). The Dissolution of Yugoslavia: Roots of the Conflict. Humanity in Action. https://www.humanityinaction.org/knowledgebase/360-the-dissolution-of-yugoslavia-roots-of-the-conflict

12. Biserko, S., \& Stanojlović, S. (2016). Russia's Soft Power Expands. In D. Stojanović, M. Samardžić \& H. Klasić (Eds.), THE WARP OF THE SERBIAN IDENTITY: Anti-westernism, russophilia, traditionalism (pp. 157-168). Belgrade: Helsinki Committee for Human Rights.

13. Boyea, E. (1995). The reverend Charles Coughlin and the Church: the Gallagher years, 1930-1937. The Catholic Historical Review, 81(2), 211-225.

14. ВSКМ. (2013). Како је убијен Небојша Крстић. BSKM. https://bskm.rs/2013/12/kako-je-ubijen-nebojsa-krstic/

15. Čongradin, S. (2019). Miša Vacić: „Junak“ sa 14 džipova. Danas. https://www.danas.rs/ ljudi/misa-vacic-junak-sa-14-dzipova/

16. Coyle, J. J. (2018). Russia's Border Wars and Frozen Conflicts: Palgrave MacMillan.

17. Cvetković, L. (2009). Obraz: niko nas ne može zaustaviti. Radio Slobodna Evropa. https:// www.slobodnaevropa.org/a/pokret_obraz/1499965.html

18. Czarnecki, G. (2007). Analogies of pre-war anti-Semitism and present-day homophobia in Poland. Beyond the pink curtain. Everyday life of LGBT people in Eastern Europe, 327-344. 
19. Damjanović, I., Novaković, D., \& Obradović, I. (2003). Human rights in the shadow of nationalism: Serbia 2002: Helsinki Committee for Human Rights in Serbia.

20. Decker, F. (2016). The "alternative for Germany:" factors behind its emergence and profile of a new right-wing populist party. German Politics and Society, 34(2), 1-16.

21. Djokić, D., \& Ker-Lindsay, J. (2010). New perspectives on Yugoslavia: key issues and controversies: Routledge.

22. Đorđević, M. (2009). Klerikalizam i antiklerikalizam u Srbiji. Republika(444-445).

23. Duncan, P. J. (1998). Changing Landmarks? Anti-Westernism in National Bolshevik and Russian Revolutionary Thought Russian Nationalism Past and Present (pp. 55-76): Springer.

24. Dzombic, J. (2014). Rightwing extremism in Serbia. Race \& Class, 55(4), 106-110.

25. Ejdus, F., \& Subotić, J. (2014). Kosovo as Serbia's sacred space: Governmentality, pastoral power, and sacralization of territories Politicization of religion, the power of symbolism (pp. 159-184): Springer.

26. Espreso. (2019). MISA VACIĆ DOBIO OGROMAN BILBORD U BEOGRADU: Svi se pitaju - pošto i ko je to platio? Espreso. https://www.espreso.rs/vesti/politika/391137/misavacic-dobio-ogroman-bilbord-u-beogradu-svi-se-pitaju-posto-i-ko-je-to-platio

27. Giaccaria, P., \& Minca, C. (2016). Life in space, space in life: Nazi topographies, geographical imaginations, and Lebensraum. Holocaust Studies, 22(2-3), 151-171.

28. Golubović, Z. T. (1995). Social change in 1990's and social character: The case of Yugoslavia. Sociologija, 37(4), 441-453.

29. Gordy, E. (2004). Serbia after Djindjic: war crimes, organized crime, and trust in public institutions. Problems of Post-Communism, 51(3), 10-17.

30. Cordy, E. D. (1999). The culture of power in Serbia. Nationalism and the destruction of alternatives. The Pennsylvania State UP.

31. Hahn Tapper, A. J. (2013). A pedagogy of social justice education: Social identity theory, intersectionality, and empowerment. Conflict Resolution Quarterly, 30(4), 411-445.

32. Hudson, K. (2003). Breaking the South Slav dream: the rise and fall of Yugoslavia: Pluto Press.

33. Hudson, R. (2003). Songs of seduction: popular music and Serbian nationalism. Patterns of Prejudice, 37(2), 157-176.

34. Ismailov, E., \& Papava, V. (2010). Rethinking Central Eurasia. Johns Hopkins University, SAIS.

35. Iveković, I. (2002). Nationalism and the political use and abuse of religion: the politicization of Orthodoxy, Catholicism and Islam in Yugoslav successor states. Social Compass, 49(4), 523-536.

36. Jiménez, R., \& Ángel, J. (2012). Las sombras de la barbarie: Confrontación de memorias colectivas en los paises exyugoslavos: Balkania.

37. Kaser, K. (2008). Patriarchy after patriarchy: gender relations in Turkey and in the Balkans, 1500-2000 (Vol. 7): LIT Verlag Münster.

38. Kaser, K., \& Halpern, J. M. (1998). Historical myth and the invention of political folklore in contemporary Serbia. Anthropology of East Europe Review, 16(1), 89-107.

39. Kaser, K., \& Katschnig-Fasch, E. (2005). Gender and Nation in South Eastern Europe: LIT Verlag Münster. 
40. Kazharski, A. (2019). Eurasian Integration and the Russian World: Regionalism as an Identitary Enterprise: Central European University Press.

41. Kolstø, P. (2016). Media discourse and the Yugoslav conflicts: Representations of self and other: Routledge.

42. Kordić, S. (2010). Jezik i nacionalizam. Zagreb: Durieux.

43. Laruelle, M. (2016). The notion of Eurasia: A spatial, historical and political construct. Questioning post-Soviet, 127-142.

44. Latas, A. (2019). SKANDALOZNI SNIMCI Miša Vacić je u jeku kampanje u Medveđi obelodanio spisak korisnika narodne kuhinje, Crveni krst se izvinio, ali TU NIJE KRAJ. Blic. https://www.blic.rs/vesti/politika/skandalozni-snimci-misa-vacic-je-u-jeku-kampanje-u-medvedi-obelodanio-spisak/9tnqw6f

45. Lucarelli, S. (2000). Europe and the breakup of Yugoslavia: a political failure in search of a scholarly explanation: Martinus Nijhoff Publishers.

46. Lukyanov, F. (2014). 18 Eurasia. Eurasian Integration-The View from Within, 290.

47. M., A. P. (2019). MUTNE RADNJE Kako je Miša Vacić prvi put PREŠAO CENZUS posle niza SKANDALOZNIH predizbornih poteza u Medvedi. Blic. https://www.blic.rs/vesti/politi$\mathrm{ka} /$ mutne-radnje-kako-je-misa-vacic-prvi-put-presao-cenzus-posle-niza-skandaloznih/ m60el60

48. Madureira, N. L. (2007). Cartelization and Corporatism: Bureaucratic Rule in Authoritarian Portugal, 1926-45. Journal of Contemporary History, 42(1), 79-96.

49. Martin, D. (2019). Closed City Christians: Theopolitics of Canonical Territory in Post-Soviet Russia. The Journal of Religion, 99(1), 59-79.

50. Melicharek, M. (2014). Foreign policy of Serbia towards Bosnia and Herzegovina before the breakup of First World War. Paper presented at the Conference proceedings, The Great War: Regional Approaches and Global Contexts, International Conference on the Occasion of the First Centennial of the Beginning of World War One, Sarajevo, 19th-21th June.

51. Mestvirishvili, M., Zurabishvili, T., lakobidze, T., \& Mestvirishvili, N. (2017). Exploring Homophobia in Tbilisi, Georgia. Journal of homosexuality, 64(9), 1253-1282.

52. Morus, C. M. (2007). Slobo the redeemer: The rhetoric of Slobodan Milosevic and the construction of the Serbian "people". Southern Communication Journal, 72(1), 1-19.

53. Moss, K. (2014). Split Europe: homonationalism and homophobia in Croatia LGBT Activism and the Making of Europe (pp. 212-232): Springer.

54. Mršević, Z. (2013). Homophobia in Serbia and LGBT rights. Southeastern Europe, 37(1), 60-87.

55. N1. (2019). Vacić pretio Zelenoviću da će završiti u Drini, da će ga zatvoriti i pljuvati. N1. http://rs.nlinfo.com/Vesti/a542469/Pretnje-Mise-Vacica-Nebojsi-Zelenovicu.html

56. Nielsen, C. A. (2010). The goalposts of transition: football as a metaphor for Serbia's long journey to the rule of law. Nationalities Papers, 38(1), 87-103.

57. O'Shea, B. (2005). The modern Yugoslav conflict 1991-1995. Routledge. ISBN, 978, 0-415.

58. Pajnik, M., \& Kuzmanić, T. (2005). Nation-states and xenophobias: In the ruins of Former Yugoslavia: Peace Institute.

59. Papava, V. (2013). The Eurasianism of Russian Anti-Westernism and the Concept of" Central Caucaso-Asia". Russian Politics \& Law, 51(6), 45-86. 
60. Pavković, A. (2000). The fragmentation of Yugoslavia: nationalism and war in the Balkans: Springer.

61. Perica, V. (2002). Balkan idols : religion and nationalism in Yugoslav states. from http:// public.eblib.com/choice/publicfullrecord.aspx? $p=3052091$

62. Pieper, M. (2018). Russkiy mir: the geopolitics of Russian compatriots abroad. Geopolitics, $1-24$.

63. Popov, Č. (2008). Velika Srbija: stvarnost i mit: Izd. Knjižarnica Zorana Stojanovića.

64. Ramet, S. P. (2005). Thinking about Yugoslavia: scholarly debates about the Yugoslav breakup and the wars in Bosnia and Kosovo: Cambridge University Press.

65. Ramet, S. P., \& Pavlakovic, V. (2007). Serbia since 1989 : politics and society under Milosevic and after. from http://public.eblib.com/choice/publicfullrecord.aspx? $\mathrm{p}=3444386$

66. Reygan, F., \& Moane, G. (2014). Religious homophobia: The experiences of a sample of lesbian, gay, bisexual and transgender (LGBT) people in Ireland. Culture and Religion, 15(3), 298-312.

67. Rheindorf, M., \& Wodak, R. (2018). Borders, fences, and limits-Protecting Austria from refugees: Metadiscursive negotiation of meaning in the current refugee crisis. Journal of Immigrant \& Refugee Studies, 16(1-2), 15-38.

68. Rogers, J., \& Kelly, U. A. (2011). Feminist intersectionality: Bringing social justice to health disparities research. Nursing Ethics, 18(3), 397-407.

69. Rosenthal, L. (2016). Incorporating intersectionality into psychology: An opportunity to promote social justice and equity. American Psychologist, 71(6), 474.

70. Sell, L. (2003). Slobodan Milosevic and the destruction of Yugoslavia: Duke University Press.

71. Smith, W. D. (1980). Friedrich Ratzel and the origins of Lebensraum. German Studies Review, 3(1), 51-68.

72. Stakic, I. (2011). Homophobia and hate speech in Serbian public discourse: how nationalist myths and stereotypes influence prejudices against the LCBT minority. Universitetet $\mathrm{i}$ Tromsø.

73. Stier, S., Posch, L., Bleier, A., \& Strohmaier, M. (2017). When populists become popular: Comparing Facebook use by the right-wing movement Pegida and German political parties. Information, Communication \& Society, 20(9), 1365-1388.

74. Stojanović, D. (2015). Private Yugoslavism and Serbian Public Opinion, 1890-1914. East Central Europe, 42(1), 9-28.

75. Tanjug. (2016a). Đurić demantuje da je Vacić savetnik u Kancelariji za KIM. Blic. https:// www.blic.rs/vesti/politika/djuric-demantuje-da-je-vacic-savetnik-u-kancelariji-za-kim/ c7gy2xg

76. Tanjug. (2016b). VOĐA "OBRAZA" PRAVOSNAŽNO NIJE KRIV Mladen Obradović oslobođen optužbi za izazivanje nereda na Prajdu 2010. godine. Blic. https://www.blic.rs/ vesti/hronika/vodja-obraza-pravosnazno-nije-kriv-mladen-obradovic-osloboden-optuzbi-za-izazivanje/8d8sdg8

77. Tašković, M. (2018). NOVA STRANKA NACIONALISTA Miša Vacić na čelu Srpske desnice, podržali ga Lav Pajkić i Marko Bulat. Blic. https://www.blic.rs/vesti/politika/nova-stranka-nacionalista-misa-vacic-na-celu-srpske-desnice-podrzali-ga-lav-pajkic-i/b19qt6d

78. Thomas, R. (1999). The politics of Serbia in the 1990s. New York: Columbia University Press. 
79. Trenin, D. (2001). The end of Eurasia: Russia on the border between geopolitics and globalization: Carnegie Endowment.

80. Umland, A. (2012). Russia's new" special path" after the Orange Revolution: radical anti-westernism and paratotalitarian neo-authoritarianism in 2005-8. Russian Politics \& Law, 50(6), 19-40.

81. Verhey, J. (2000). The spirit of 1914: militarism, myth, and mobilization in Germany (Vol. 10): Cambridge University Press.

82. Warren, D. I. (1996). Radio priest: Charles Coughlin, the father of hate radio: Free Press.

83. Zakošek, N. (2008). Democratization, state-building and war: The cases of Serbia and Croatia. Democratisation, 15(3), 588-610.

84. Žerjavić, V. (1998). Great Serbia: tragic outcome. Globus, 9. 